\title{
ЭКОЛОГО-ЦЕНОТИЧЕСКОЕ РАЗНООБРАЗИЕ ВОДНЫХ И ОКОЛОВОДНЫХ БИОЦЕНОЗОВ РЕКИ ПСЁЛ
}

\section{ECOLOGICAL AND COENOTIC DIVERSITY OF AQUATIC AND NEAR-WATER BIOCENOSES OF THE PSEL RIVER}

E. Dmitrieva

S. Zherdeva

Summary. This article reflects the results of the study of the ecologicalcenotic and species diversity of the flora and fauna of the Psel river. The ecological assessment of water and near-water biocenoses is given and their role in the formation of the water state in the Psel river is determined. The threat of anthropogenic influence on the populations of rare and endangered species that have a disjunctive or border area, especially sensitive to human economic activity, has been established.

Keywords: Psel river, ecological and cenotic diversity, coastal communities, anthropogenic activity, ecological transformation.
Дмитриева Екатерина Леонидовна

К.б.н., дочент, Курский государственный университет

sv-dmitr@yandex.ru

Жердева Светлана Владимировна

К.б.н., дочент, инженер по охране окружающей среды (эколог), ОКУ «Дирекция по управлению особо охраняемыми природными территориями Курской области»

s.v.zherdeva@gmail.com

Аннотация. В данной статье отражены результаты исследования эколого-ценотического и видового разнообразия флоры и фауны реки Псёл. Дана экологическая оценка водных и околоводных биоценозов и определена их роль в формировании состояния воды в реке Псёл. Установлена угроза антропогенного влияния на популяции редких и исчезающих видов, имеющих дизъюнктивный или пограничный ареал, особенно чувствительных к хозяйственной деятельности человека.

Ключевые слова: река Псёл, эколого-ценотическое разнообразие, прибрежные сообщества, антропогенная деятельность, экологическая трансформация.

Псёл использовали маршрутный метод, метод трансект и метод пробных площадок. Исследования проводились в летний период 2019 года.

По результатам исследований было установлено, что видовой состав прибрежно-водной растительности реки Псёл представлен 102 видами. Прирусловая часть в пойме реки Псёл выражена довольно слабо и прослеживается лишь на некоторых участках полосой шириной 10-15 м. Часто она занята зарослями различных кустарниковых Salix triandra, Salix viminalis и др. Пониженные участки прирусловой поймы (высота 1-1,5 м над меженью) занимают ассоциации с преобладанием Лисохвоста лугового [3]. Из злаков появляются Beckmannia eruciformis, Deschampsia caespitosa, Agrostis stolonifera, среди разнотравья доминируют Ranunculus repens, Potentilla anserina, Symphytum officinale, Lythrum salicaria, Rumex confertus, Filipendula ulmaria, Geum rivale и др.

Ведущую роль при дальнейшем понижении рельефа начинают играть сообщества с преобладанием различных видов осок - Carex vulpina, Carex cespitosa, Carex nigra, Carex vesicaria, Carex acuta и др. Обычно они занимают округлые или продолговатые запа- 


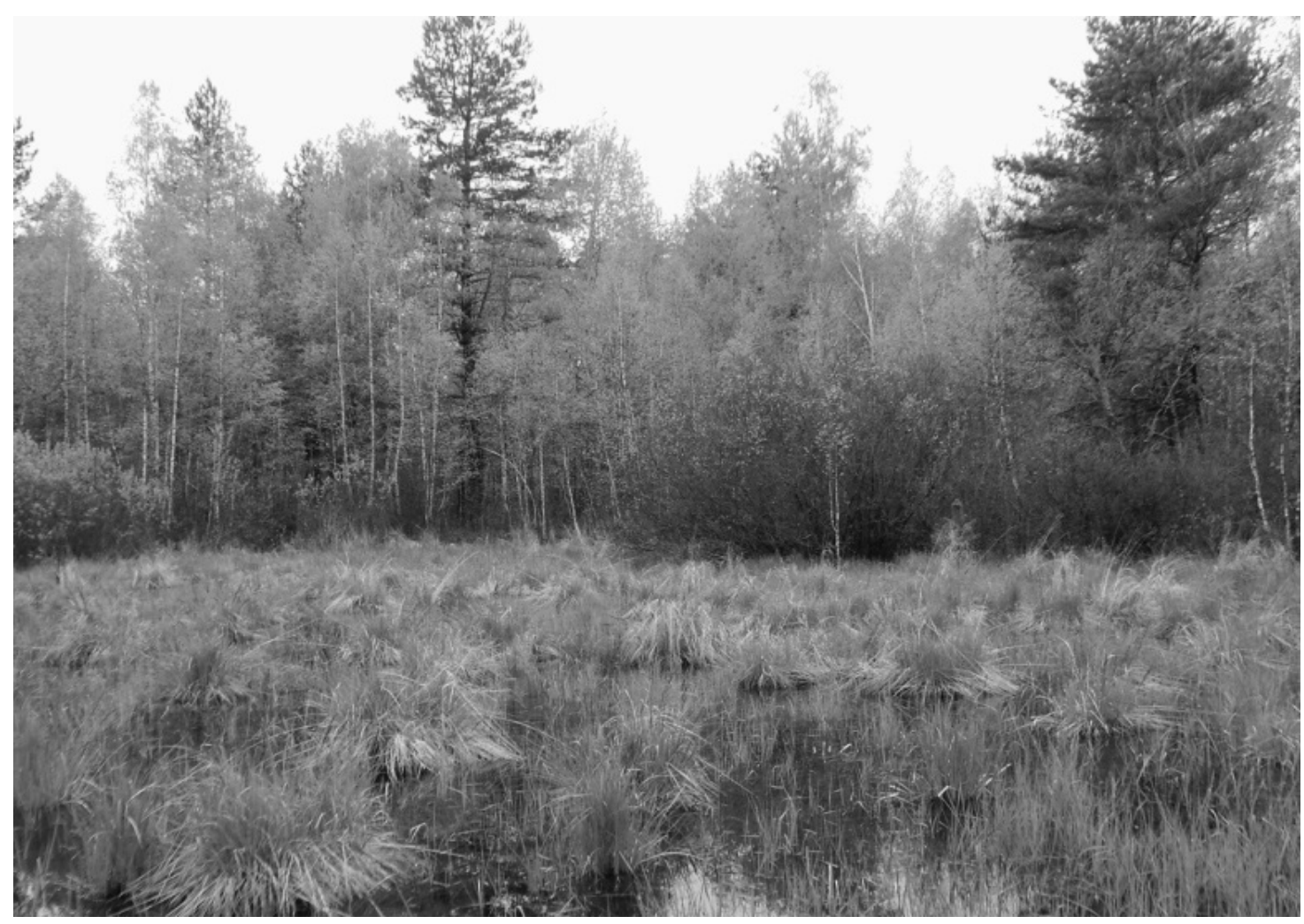

Рис. 1. Осоковое болото на песчаной террасе реки Псёл в окрестности урочища Маховская дача

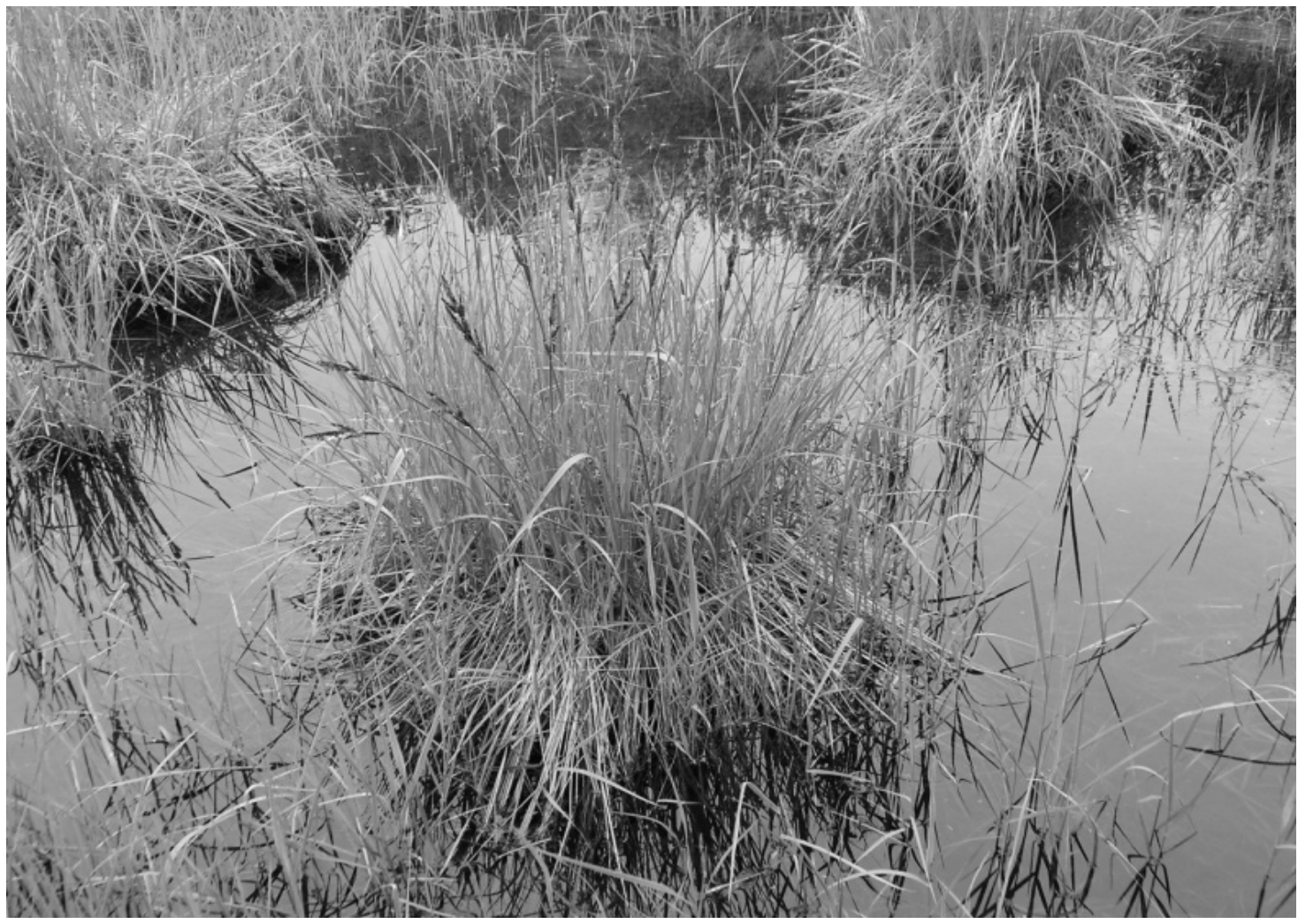

Рис. 2. Прибрежно-водные растения. Осока омская 
дины различных размеров. Кроме осок, в них обычны Eleocharis palustris, Ranunculus repens, Caltha palustris, Lythrum salicaria и др., центр западины занимает водно-болотная растительность. Болото Борки - памятник природы, на территории которого охраняются: пальчатокоренник мясо-красный. Участок Центрально-Черноземного государственного заповедника «Пойма Псла», является уникальным местом сохранения биоразнообразия Попселья. Здесь встречается водное растение Вольфия бескорневая, занесенная в Красную книгу Курской области.

Прибрежные сообщества реки Псёл сформированы различными ассоциациями. Ведущую роль в них играют ассоциации с господством Phragmites communis, где массовыми видами выступают Carex riparia, Carex pseudocyperus, Carex rostrata, Equisetum fluviatile, Lysimachia vulgaris, Cicuta virosa, Scirpus lacustris, Typha latifolia, Typha angustifolia. Из деревьев наиболее обычны ольха и ива пепельная. Рогозовые и хвощевые ассоциации начинают развиваться при снижении проточности и заилении дна, обычными видами в них являются Comarum palustre, Glyceria fluitans, Sparganium simplex, Carex acuta, Carex vesicaria, Alisma plantago-aquatica.

Ассоциации тростника обыкновенного с различными видами осок (Phragmtietum communis caricosum) составляют основу растительного сообщества пойменных болот [1]. К часто встречающимся видам осок относятся Carex riparia, Carex cespitosa, Carex acuta, Carex omskiana, Carex nigra, Carex rostrata. В чистом виде сообщества осок наблюдаются крайне редко, все чаще мы их встречаем в смеси с другими видами, образуя гипново-осоковые, хвощево-осоковые, вахтово-осоковые и другие ассоциации с преобладанием в травяном покрове Poa palustris, Calamagrostis canescens и гигрофильного разнотравья - Caltha palustris, Epilobium hirsutum, Epilobium palustre, Galium palustre, Lycopus europaeus, Menyanthes trifoliata, Naumburgia thyrsiflora (рис. 1-2).

Сбор материала по изучению фауны водных и околоводных биоценозов реки Псёл осуществлялся в весенне-летний период на протяжении 2018-2019 годов.

В результате исследования фауны водных беспозвоночных реки Псёл были определены как донные (бентос), так и плавающие в воде (планктон) организмы. К крупным представителям бентоса реки относятся двустворчатые моллюски (перловицы и беззубки), которые активно участвуют в очищении воды от взвешенных частиц. Перловица обыкновенная - индикатор чистоты воды, фильтратор, местами встречается очень редко. К массовой гибели приводят загрязнения стоками с полей ядохимикатов и удобрений, сброс неочищенных отходов свиноферм. Лунка речная, статус 3 в Красной книге Курской области, встречается только в бассейне Псла [2]. Большая доля в планктоне приходиться на мелких рачков - дафний и циклопов, а также простейших - амеб, инфузорий и жгутиковых, которые являются пищей для мелких рыб. В местах зарастания водоема эколого-ценотическое разнообразие имеет иной характер, который приобретает в связи с избытком органических веществ и недостатком кислорода. К преобладающим видам относятся брюхоногие моллюски (прудовики, катушки, лужанки), пиявки и представители типа членистоногих. Наиболее многочисленно представлен класс насекомые: стрекозы (красотки, стрелки), ручейники, водомерки (водомерка болотная, водомерка прудовая), водные жуки представлены в основном семейством плавунцы (полоскун борозчатый, нырялка, водяник), крайне редко встречаются большие жуки - плавунец окаймленный и плавунец широкий, водолюб черный большой занесен в Красную книгу Курской области (2017). На береговой растительности встречается жук радужница. Из семейства комары настоящие встречаются: кусака серый, кусака коленчатый, комар-пискун из семейства мошки несколько родов мошек: Eusimulium Roub., Odagmia Meigen, Simulium Latr. Семейство мокрецы представлено двумя родами: мокрец черный, мокрец настоящий. Стрекозы решетчатая (большая голубая), коромысло большое и дозорщик-повелитель встречаются редко, последний вид занесен в Красную книгу Российской Федерации.

Ихтиофауна в Псле представлена 28 видами, относящиеся к 5 отрядам: отряд миногообразные (украинская минога Красная книга Российской Федерации), отряд щукообразные (щука обыкновенная), отряд карпообразные (плотва, голавль, язь обыкновенный, верховка, красноперка, жерех, линь, пескарь обыкновенный, горчак, уклейка обыкновенная, густера, лещ, сазан, карась золотистый, карась серебряный, голец, щиповка обыкновенная, вьюн, сом обыкновенный), отряд трескообразные (налим), отряд окунеобразные (окунь обыкновенный, судак, ерш обыкновенный). В реке Псел обитает быстрянка русская (подвид занесен в Красную книгу Российской Федерации) и елец Данилевского входит (2018 г.) в перечень видов животных, рекомендованных к занесению в Красную книгу Курской области.

Наибольшее распространение из земноводных и пресмыкающихся в бассейне реки Псёл в прежние годы имели краснобрюхая жерлянка, остромордая, гибридная и озерная лягушки, зеленая жаба. В настоящее время земноводные относятся к наиболее уязвимой группе позвоночных животных. Восточное побережье оз. Клюквенное, граничащее с сельхоз полями бывает усеяно погибшими земноводными, в том числе три- 
тонами- гребенчатый и обыкновенный (Красная книга Курской области) [2]. Чаще встречаются рептилии: прыткая ящерица, обыкновенный уж. Живородящая ящерица - редкий охраняемый вид. Редким и очень уязвимым видом является черепаха болотная (статус 1, под угрозой исчезновения в Красной книге Курской области).

Орнитофауна Псла представлена более 150 видами. По берегам реки Псёл наблюдались норы береговых ласточек, зимородков. Серые и большие белые цапли были отмечены в зарослях камыша. На открытых отмелях наблюдали трясогузок и куликов. Из наиболее часто наблюдаемых нами птиц можно отметить следующие виды: желтая трясогузка, камышевка дроздовидная, иволга, зеленушка, дрозд-рябинник, соловей, серая ворона, сойка, скворец, козодой занесен в Красную книгу Курской области, редок. Выпь большая, волчок,

Из млекопитающих, встречающихся на исследуемой территории, можно отметить дикого кабана, зайца-русака, крота европейского, белку, ежа, ласку, водяную и рыжую полевку, речного бобра, места обитания, которого заметить, не очень сложно - поваленные деревья по берегам водоема, знаменитые плотины этих речных строителей, хатки, в которых они живут. Появление бобров в реках и особенно постройка ими запруд оказывает благоприятное воздействие на экологическую обстановку водных и приречных биотопов. В образовавшемся разливе поселяются многочисленные моллюски и водные насекомые, которые в свою очередь привлекают водоплавающих птиц, которые на лапках приносят рыбью икру. Поваленные бобрами деревья служат кормом для зайцев, которые обгладывают кору со стволов и ветвей. Горностай - один из редких видов побережий Псла и озер в пойме. Нередко подвергаются уничтожению водные обитатели, в том числе кутора обыкновенная и малая в результате браконьерского применения электроудочек.

По берегам густо заросших травой можно встретить небольшие хатки из стеблей водных растений (тростника, рогоза, осоки) скрепленных илом - это надводные жилища ондатры. Ондатра проникла в наши водоемы из Сумской области (интродуцент из Северной Америки). Ондатра плодовита и легко приспосабливается к изменениям среды обитания. Она является конкурентом водной полевки.

Сохранение биоразнообразия занимает особое место среди основных экологических проблем современности. Проведение идентификации и инвентаризации видового состава наземно-водных экосистем реки Псёл поможет определить последствия загрязнений, в какой мере данные воздействия повлияли на нарушение экосистемы. Для сохранения биологического разнообразия остро стоит задача сохранения наиболее значимых местообитаний. К основным мероприятиям по сохранению местообитаний можно отнести: поддержание оптимального гидрологического режима путём сокращения стока через отдельные элементы мелиоративной сети, создание ООПТ, прекращение выпаса скота по поймам как самого Псла, так и его притоков, организация управляемого сенокошения, реставрация водно-болотных угодий на месте заброшенных сельскохозяйственных земель.

\section{ЛИТЕРАТУРА}

1. Галяс А.В. Экологическая характеристика водно-болотной растительности заболоченной поймы реки Псёл // Болота и биосфера: Материалы 7-й Всероссийской с международным участием научной школы молодых ученых. Томск, 2010. С. 152-156.

2. Красная книга Курской области: редкие и исчезающие виды животных, растений и грибов. Департамент эколог. безопасности и природопользования Курск. обл. Калиниград; Курск: ИД Рост-ДОАФК, 2017. 380 с.

3. Полуянов А.В. Флора Курской области. Курск: КГУ, 2005. 264 с.

( Дмитриева Екатерина Леонидовна ( sv-dmitr@yandex.ru ), Жердева Светлана Владимировна ( s.v.zherdeva@gmail.com ). Журнал «Современная наука: актуальные проблемы теории и практики» 